\title{
THE HIGH WIND OVER PHILADELPHIA, PA., JANUARY 23, 1955
}

\author{
BENJAMIN RATNER \\ Climatological Services Division, U. S. Weather Bureau, Washington, D. C.
}

On January 23, 1955, a teletypewriter report from Philadelphia indicated a wind speed of 396 knots at 23,000 feet, for the $1500 \mathrm{GMT}$ observation. This report has since been the subject of much discussion among meteorologists.

Because high winds are important for many meteorological and operational problems it is desirable to establish whether or not an extreme upper air wind speed was recorded. Accordingly, a thorough study was made of the pertinent wind record and of the synoptic situation prevailing at the time. The findings lead to the conclusion that a mechanical breakdown, probably due to power failure, occurred directly after the 11th minute (approx. $13,000 \mathrm{ft}$.) of the sounding, and that all data above that point are entirely unreliable. It is estimated from a space-time analysis of available data that winds at 23,000 feet were alound 200 knots, and that there was an increase with height to a probable maximum of about 265 knots at 32,000 feet. The general procedures and evidence on which these conclusions were based are discussed below.

For the report in question, the rawin tape produced by the GMD-1A recorder, which was set to give readings at 6-second intervals, contains two successive readings with identical time entry (11.2 minutes), but with different angle readings. It is difficult to determine completely what happened to the equipment at this point, but the presumption is that a disruption of power to the rawin set occurred. At this point the balloon was at approximately 13,000 feet.

To assist in analyzing the synoptic situation, a series of isotach charts was prepared for various transmission levels at $1500 \mathrm{GMT}$, January 23, and for 6 and 12 hours before and after that time. In this manner, the wind pattern was examined as to time, space, and height. Winds through 12,000 feet for Philadelphia were consistent with other winds in the area. The 12,000-feet chart shows 61 knots at Pittsburgh, 62 at Harrisburg, 46 at Washington, 67 at Philadelphia, and 27 at Hempstead, Long Island. At levels above 12,000 feet, however, winds at Philadelphia increasingly diverged from the isotach pattern established by other stations. At 14,000 feet Pittsburgh reported 66 knots, Harrisburg 62, Washington 83, Philadelphia 183, and Hempstead 60. At 23,000 feet (the highest level reported for Philadelphia), Pittsburgh reported 142 knots, Washington 120, Philadelphia 396, and Hempstead 140 knots. As can be seen, the discord in synoptic continuity of winds occurs somewhere between 12,000 and 14,000 feet, which coincides with the height of the mechanical breakdown mentioned above.

Comparison of winds through time at surrounding stations indicates an orderly progression at each of the stations except Philadelphia. The wind speeds at 23,000 feet were reported as follows:

\begin{tabular}{|c|c|c|c|c|c|}
\hline & $\begin{array}{c}\text { Jan. } 23 \\
0 \$ 00 \text { GMT }\end{array}$ & 0900 GMT & $1500 \mathrm{GMT}$ & $2100 \mathrm{GMT}$ & $\begin{array}{c}\text { Jan. } 24 \\
0800 \text { GMT }\end{array}$ \\
\hline Washingtor & 201 & & 120 & 137 & 122 \\
\hline Philadelphia & 136 & 156 & 1396 & 156 & 15 \\
\hline Hempstead $\ldots \ldots$ & $-\ldots-\ldots$ & 128 & 140 & 102 & 130 \\
\hline
\end{tabular}

All winds at the 0900,1500 , and 2100 GMT observation times were primarily westerly without exception.

Reports from all stations in the vicinity of Philadelphia indicated a rather regular increase of wind speed with height, to a maximum of about 32,000 feet. If the winds at Philadelphia were to be similarly extrapolated with height to 32,000 feet, from the reported figure of 396 knots at 23,000 feet, a maximum wind of over 600 knots would result.

The synoptic situation on January 23 indicated extremely high winds over the Philadelphia area; in fact, this was one of the highest wind regimes observed over the area. The jet stream appeared to be moving slowly northward, with its maximum speed at about 32,000 feet.

Computations of possible wind shear, based on winds at nearby stations, indicate the extreme improbability of winds of the magnitude reported, and suggest probable wind speeds of near 200 knots at 23,000 feet, and a probable maximum of 265 knots at 32,000 feet, as stated above. Differential analyses made by 10 analysts in WBAN Analysis Center gave similar results [1].

\section{REFERENCE}

1. F. W. Burnett, High Winds over Philadelphia at 1500 GMT, January 23,1955 , U. S. Weather Bureau, Washington, D. C., February 10, 1955 (intra office memorandum report, unpublished). 
Blank page retained for pagination 